九州大学学術情報リポジトリ

Kyushu University Institutional Repository

\title{
THE OCCURRENCE OF THE SUBFAMILY LEPTANILLINAEIN JAPAN*(Hymenoptera, Formicidae)
}

Yasumatsu, Keizo

https://doi.org/10.5109/2340

出版情報: ESAKIA. 1, pp.17-20，1960-01-20. Hikosan biological laboratory, Faculty of Agriculture, Kyushu University バージョン :

権利関係 : 


\title{
THE OCCURRENCE OF THE SUBFAMILY LEPTANILLINAE IN JAPAN*
}

\author{
(Hymenoptera, Formicidae)
}

By

\section{Keizô Yasumatsu}

The subfamily Leptanillinae has been represented by three genera (Leptanilla, Leptomesites and Phaulomyrma) and sixteen species, and its range of geographical distribution is peculiar. It is found in two islands in the Mediterranean Sea, North Africa, India, Ceylon, Malaya, Java and in the southwest of Australia. $\mathrm{N}$ ot a single species of the subfamily has hitherto been discovered in China or Japan.

To my surprise one species of the genus Leptanilla was recently found on Mt. Hiko, Kyushu, Japan, by Messrs. K. Morimoto and R. Morimoto.

This species represents a new, and the thirteenth, species of the genus, very different from any other known member of the group. The occurrence of the subfamily in Japan suggests that the ants of this group originated in Tropical India and from this original center long ago dispersed in three directions.

Before going further I gratefully acknowledge Dr. William L. Brown, Jr., of the Museum of Comparative Zoölogy at Harvard College for his kind help in the preparation of this paper. I appreciate very much the help of $\mathrm{Mr}$. R. Ishikawa, who has been cooperative in copying the original descriptions of Forel's Leptanilla species. I also wish to thank Messrs. R. Morimoto and K. Morimoto for their efforts in finding such a rare and interesting species of Leptanilla in Japan.

\section{Leptanilla morimotoi sp. nov.}

Worker. Head flattened above, oblong, about 1.4 times as long as wide, widest at the middle, as wide in front as behind, with posterior corners rounded and posterior border feebly concave, about 1.5 times as wide as propodeum, very

* Contribution Ser. 2, No. 54, Entomological Laboratory, Kyushu University, Fukuoka.

Contribution Ser. 2, No. 7, Hikosan Biological Laboratory, Kyushu University, Hikosan. 
slightly wider than first gastric segment. Mandibles narrow, with three-toothed masticatory margins, the terminal tooth slightly curved and acute, the two remain. ing ones stout and acute as shown in Fig. 1. Clypeus without distinct posterior

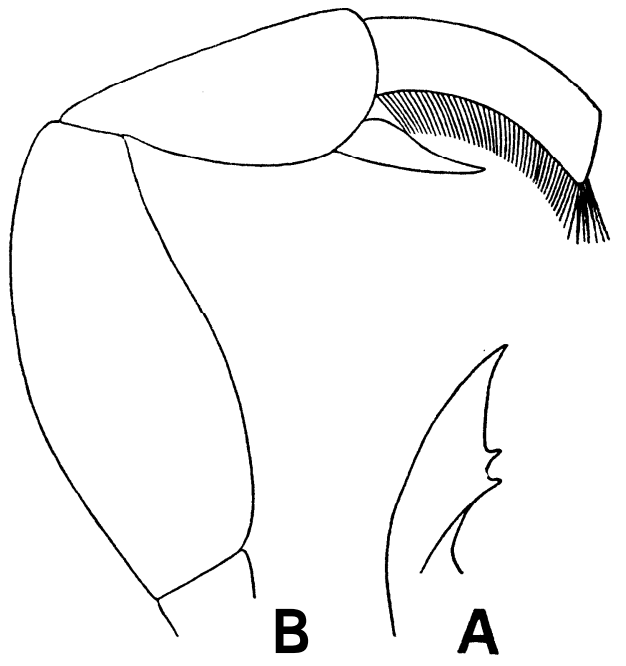

Fig. 1. Leptanilla morimotoi sp. nov.,

Worker. A, Mandible. B, Femur, tibia and basitarsus of fore leg. border, its anterior margin very slightly produced in the middle as a broadly rounded lobe. Antennae moderately stout ; apex of scape reaching far beyond the middle of head; relative lengths (widths) of the segments-60 (30) : 30(20) : 21.5(24) :15(25) :15(20) : 15 (26) :16(28) :20(30) :20(30):20(30) : $20(30): 56(30)$.

Thorax much narrower than head, the sides slightly convergent posteriorly, distinctly shorter than abdomen, about twice as long as petiole and postpetiole taken together, flattened dorsally and not deeply notched in profile at the promesonotal suture; pronotum subovoidal, wider than mesepinotum which is longer than pronotum, with feebly rounded subparallel sides; base of mesepi notum distinctly constricted in aorsal aspect. Legs relatively short and very stout, all legs of similar shape, relative lengths of the segments of fore legs-femur : tibia : basitarsus=18:12:9, fore femur about twice as long as wide, fore tibia as long as wide, fore basitarsus three times as long as wide and curved. Petiole very distinctly longer than wide (about 1.6 times as long as wide), much narrower than epinotum, gradually rounded anteriorly, posteriorly with rounded subparallel sides. Postpetiole nearly as wide as long or high, slightly widened posteriorly, distinctly shorter than petiole, but distinctly wider than petiole. Ventral side of petiole and postpetiole convex, with a low but distinct median platelike projection at the basal half of petiole, with a high median one on the whole length of postpetiole.

Gaster elongate-elliptical, anterior border of first segment slightly concave, first segment narrower than head, first, second and third almost the same width.

Body entirely pale yellowish-brown, smooth, densely covered with short microhairs which are longer and coarser on gaster, basal area of second, third and fourth gastric segments hairless.

Length ca. $1.5 \mathrm{~mm}$.

Type locality. Mt. Hiko (Hikosan), Fukuoka Prefecture, Kyushu.

Holotype. Worker, 4. iv. 1958, Mt. Hiko, K. Morimoto leg. 
Paratypes. 1 worker, the same data as the holotype, 6 workers, 12-15, vii. 1958, Mt. Hiko, R. Morimoto leg. All were collected at an altitude of 600 meters, in the soil of bamboo bushes, in the campus of the Hikosan Biological Laboratory, Kyushu University, Hikosan. Preserved in the collection of the Entomological Laboratory of Kyushu University, one paratype in the collection of the Museum of Comparative Zoology at Harvard College and another one in the collection of the British Museum (Nat. Hist.).

This new species is allied to Leptanilla butteli Forel, 1913, of Selangor and $\boldsymbol{L}$. havilandi Forel, 1901, of Singapore. But in butteli the petiole is much wider than long and as wide as postpetiole, and each of the flagellar segments is almost twice as wide as long. In havilandi the petiole is somewhat longer than wide and the clypeus is provided with two small teeth on its anterior margin.

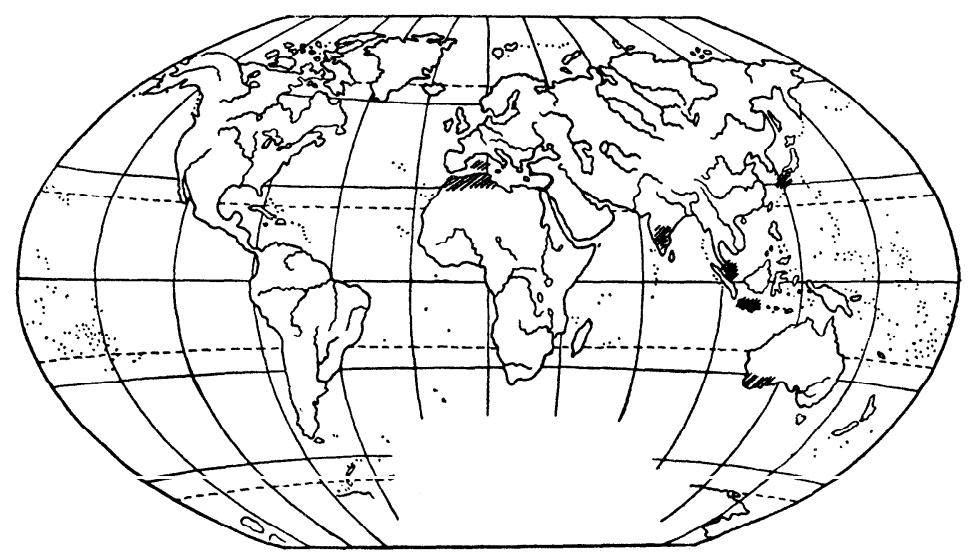

Fig. 2. A map showing the distribution of the species of Leptanillinae.

\section{Appendix :}

List of the species of the Leptanillinae

Genus Leptanilla Emery, 1913

1. butteli Forel, 1913. . . . . . . . Malaya : Selangor

2. doderoi Emery, 1915 . . . . . . . . Sardinia : Teulada

3. exigua Santschi, 1908. ......... Tunis : Kairouan

4. havilandi Forel, 1901 ........ . Malaya : Singapore

5. minuscula Santschi, 1907 . . . . . . . Tunis : Kairouan

6. morimotoi Yasumatsu, 1960 . . . . . . . Japan : Hikosan

7. nana Santschi, 1915 ........ . Tunis : Kairouan

8. santschii Wheeler et Wheeler, 1930. . . . . Java : Buitenzorg 
9. revelierei Emery, 1870 ......... Corsica, Sardinia (var. bimaculata Emery, 1899)

r. chobauti Emery, 1899. ......... Morocco : Tangier r.sardoa Emery, 1916 . . . . . . . Sardinia: Carloforte

10. swani Wheeler, 1932 . . . . . . . W. Australia: Chittering

11. tenuis Santschi, 1907 ....... Tunis : Kairouan

12. theryi Forel, 1903. . . . . . . . . E. Algeria, Tunis: Sousse

13. vaucheri Emery, 1899. . . . . . . Morocco: Tangier

Genus Leptomesites Kutter, 1948

1. escheri Kutter, 1948. . . . . . . . . . India

Genus Phaulomyrma Wheeler et Wheeler, 1930

2. javana Wheeler et Wheeler, 1930. .... Java : Buitenzorg

2. tanit Santschi, 1907. . . . . . . . Tunis : Kairouan

\section{Explanation of Plate 5}

Leptanilla morimotoi sp. nov., worker. 
EsAkIA No. 1, 1960

Plate 5

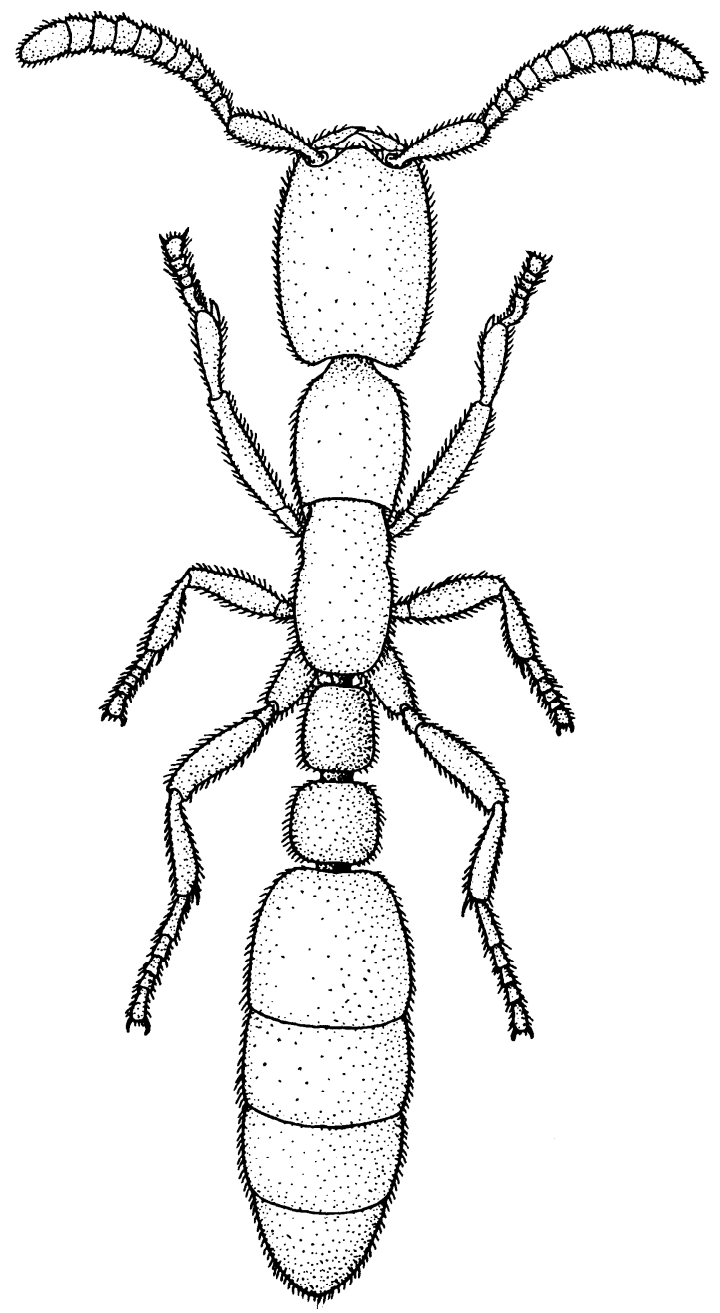

